\title{
Late Quaternary stratigraphy and morphogenesis in the Danish eastern North Sea and its relation to onshore geology
}

\section{B. Larsen ${ }^{*}$ \& L.T. Andersen}

Geological Survey of Denmark and Greenland, GEUS, øster Voldgade 10, DK 1350 Copenhagen K, Denmark

* Corresponding author. Email: bil@geus.dk

Manuscript received: March 2004; accepted: March 2005

\begin{abstract}
Geological structures and Late Quaternary stratigraphy of the shallow subsurface along the southernmost Danish North Sea coast have been investigated using seismic data and shallow boreholes. A large-scale glaciotectonic thrust complex has been mapped in an area of $15 \mathrm{~km}$ by $40 \mathrm{~km}$ in the Fanø Bugt area. The affected succession consists of Neogene and Quaternary sediments deformed down to a depth of $200-360 \mathrm{~m}$. A kinetostratigraphic correlation to onshore glaciotectonic deformation suggests that the deformation took place during a westward advance stage of the Late Saalian (Warthe) glaciation. The western limit of the glaciotectonic structures constitutes an N-S striking deformation front situated $35 \mathrm{~km}$ off the west coast. Based on the glacial stratigraphy outside the deformation front, it is suggested that the same ice advance that caused the glaciotectonic deformation, eroded the top of the thrust sheets, and subsequently deposited a lower unit of meltwater sediments and an upper heterogenous glacigenic unit. The upper glacigenic unit forms a bank about $30 \mathrm{~km}$ offshore. Between the bank and the shore, the surface of the Saalian glacial landscape forms a wide depression ca. $50 \mathrm{~m}$ below sea level. This basin has controlled deposition in the area since the late Saalian and is filled with sediments of late Saalian, Eemian, Weichselian and Holocene age. The base of the Holocene marine deposits is thus a flat erosional surface extending eastward several kilometres below the onshore coastal areas and the northern Wadden Sea. This surface was transgressed 8800 years ago. An inverted, in plan view T-shaped, Holocene sand accumulation approximately $25 \mathrm{~km}$ long, $30 \mathrm{~km}$ wide and $15-25 \mathrm{~m}$ thick is situated on top of this surface at Blåvands Huk. According to recent estimates by the Danish Coastal Protection Board some 2.5 million $\mathrm{m}^{3}$ sediments are supplied annually to the system from the north. In the last 3000 years, $25 \mathrm{~km}$ of the west coast and the associated shoreface slope have prograded ca. $3 \mathrm{~km}$ towards the west forming a barrier spit complex. Large aeolian dunes and cover sands now conceal the spit complex. Extending twenty km west of Blåvands Huk is a highly dynamic bank, the Inner Horns Rev, with active sand-accumulation on the slopes. The Inner Horns Rev bank has grown ca. $3.5 \mathrm{~km}$ westward during the last 800 years. The deposits seem to be sourced by the coastal longshore sand transport from the north. The Outer Horns Rev was previously assumed to be a Saalian terminal moraine. However, this investigation reveals that it is also mainly a Holocene marine accumulation landform, but sourced from the west. Other sand accumulations, which are situated $20-30 \mathrm{~km}$ west of the coast, are probably sourced from both the south and the west.
\end{abstract}

Keywords: Denmark, North Sea, Saalian, Eemian, Weichselian, Holocene, glaciotectonics, spit systems, coastal development

\section{Introduction}

The easternmost $50 \mathrm{~km}$ of the Danish North Sea is shallow with water depths mainly less than $30 \mathrm{~m}$ (Fig. 1). The westernmost point of Denmark is Blåvands Huk; the corner where the straight west coast of Jutland meets the northernmost part of the tidal Wadden Sea (Fig. 1). Horns Rev protrudes about $40 \mathrm{~km}$ into the North Sea west of Blåvands Huk. The Reef is a complex of shallow submarine sandbanks rising to $2-7 \mathrm{~m}$ water depths while the surrounding depths are in the range of $20-30 \mathrm{~m}$ (Fig. 1). From regional studies it is known that the entire area was covered by ice-sheets during the Elsterian and the Saalian 


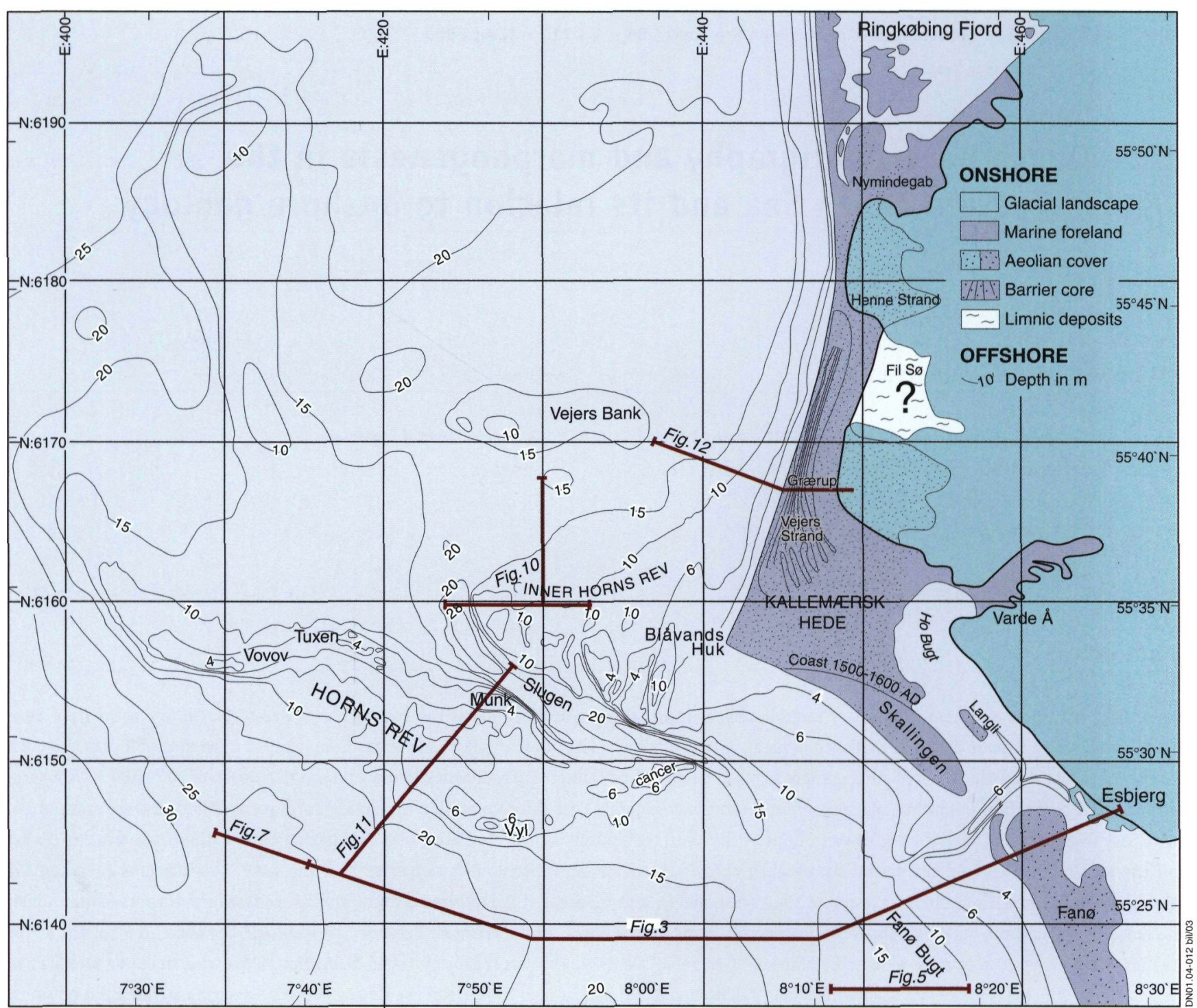

Fig. 1. Bathymetric map with names and locations of illustrations. The map is based on Danish Nautical Map Nos. 61. UTM zone 32, coordinates in $\mathrm{km}$. Depths refer to mean spring low tide which is approximately $1 \mathrm{~m}$ below DNN (Danish ordnance datum). Geological onshore map shows the extension of the Holocene marine foreland (land area formed by deposition of marine and shore deposits and the associated aeolian cover), (modified from Nielsen et al., 1995 and Aagaard et al., 1995).

glaciations (Ehlers, 1990), and that it was ice-free south of $56^{\circ} 20 \mathrm{~N}$ during the Weichselian (Leth, 1996). The palaeo North Sea extended across most of the area in part of the Eemian interglacial period (Konradi et al., 2005). In the adjacent land areas (western Jutland) the old Saalian glacial landscape (Danish term: 'bakke- $\varnothing^{\prime}$ ) protrudes above the flat Weichselian proglacial plains and river valleys. The geological structure of the bakke-ø landscape is complex due to extensive glaciotectonic deformations. Similar structures have been discovered in the offshore region (Huuse \& Lykke-Andersen, 2000; Andersen, 2004) and the morphology of Horns Rev (Fig. 1) has been interpreted as a system of Saalian terminal moraines pushed up from the north (Jessen, 1925; Reinhard, 1974; Lüneburg, 1967). However, Gripp (1944) previously had argued that Horns Rev was a Holocene sand accumulation.
It is generally assumed that the Weichselian proglacial river plains extended westward off the west coast of Jutland forming the featureless seafloor in this part of the North Sea (HoumarkNielsen \& Kjær, 2003). However, very little has been published on observations of the Quaternary sequence below the seafloor within $50 \mathrm{~km}$ off the west coast of Denmark (Lüneburg, 1967; Foged, 1987; Leth et al., 2004). A rim of Holocene marine forelands such as spits and barriers has developed between the glacial landscape and the present day coast (Fig. 1). In the Wadden Sea area, this rim is a prism of mainly submarine tidal deposits (Bartholdy \& Pejrup, 1994) protected by a row of barrier islands from Røm $ø$ in the south, to Fan $\emptyset$ and the peninsular Skallingen in the north (Aagaard et al., 1995; Bartholdy \& Pejrup, 1994). Recent studies indicated that the seabed off these areas was acting as a depocenter in the Holocene (Leth et al., 2004). 
The aim of this paper is to describe the Late Quaternary geology of the eastern Danish North Sea south of $55^{\circ} 50^{\prime} \mathrm{N}$ and east of $7^{\circ} 20^{\prime} \mathrm{E}$ (Fig. 2) and to discuss its relation to the onshore geology. Special attention is given to the offshore extension of the Saalian and Weichselian deposits and the relation between the development of the Holocene marine forelands onshore and the Holocene deposits offshore.

\section{Materials and methods}

The investigation of the northern and southern part of the area is based on seismic data with different resolution. In the Fanø Bugt the deeper parts of the sedimentary sequence $(50-1000 \mathrm{~m}$ ) are studied using high-resolution multi-channel reflection seismic data acquired by the University of Aarhus and GEUS (Fig. 2). Post-stack bandwidth of the migrated data is $50-200 \mathrm{~Hz}$. The vertical and horizontal resolution is about $5 \mathrm{~m}$ and $20 \mathrm{~m}$ respectively at best, and the vertical penetration is $1500 \mathrm{~ms}$ two way travel-time (TWT) or roughly $1.4 \mathrm{~km}$. The top 50 - 100 ms TWT is often masked by water-layer multiples on these data. The investigations of the Horns Rev area and the area north of $55^{\circ} 50^{\prime} \mathrm{N}$ are mainly based on interpretation of high-resolution single channel seismic data acquired with various equipment since 1982; Sparker (0.8 - 1.2 KHz), Boomer $(0.6-2.5 \mathrm{KHz})$, Pinger $(3.5 \mathrm{KHz})$ or Chirp (X-star $1-7 \mathrm{KHz}$ ) (Fig. 2). In general is the penetration in the range of $1-100 \mathrm{~m}$ and the resolution is about $1 \mathrm{~m}$.

Data from technical investigations (i.e. DGI, 1982; Kuijpers, 1993, 1995; Kystdirektoratet, 2001) were compiled and reinterpreted. New data acquired by GEUS during joint projects with the Danish Coastal Authority from 1998 to 2001 (Larsen \& Leth, $2001 \mathrm{a}, \mathrm{b})$ provided the opportunity to examine the sedimentary conditions along the coast north of Blåvands Huk. The Fanø Bugt area is only covered by high-resolution single channel seismic data to a limited extent (Fig. 2). A seismic velocity of $1500 \mathrm{~ms}^{-1}$ has been applied in the time/depth conversion of the shallow seismic profiles while the multichannel seismic profiles have been converted using a velocity of $1800 \mathrm{~ms}^{-1}$, except for contour maps where a velocity of $1500 \mathrm{~ms}^{-1}$ was applied. The seismic reflection patterns are described according to Mitchum et al. (1977).

Offshore the acoustic data are supplemented with lithological analysis on approximately fifty vibrocores $6-10 \mathrm{~m}$ deep (Larsen \& Leth, 2001a, b) and 6 geotechnical boreholes 40 - $50 \mathrm{~m}$ deep (Fig. 2). The onshore observation points are from water wells and geotechnical boreholes stored in a
Fig. 2. Track map of seismic lines and locations of boreholes used in this study.

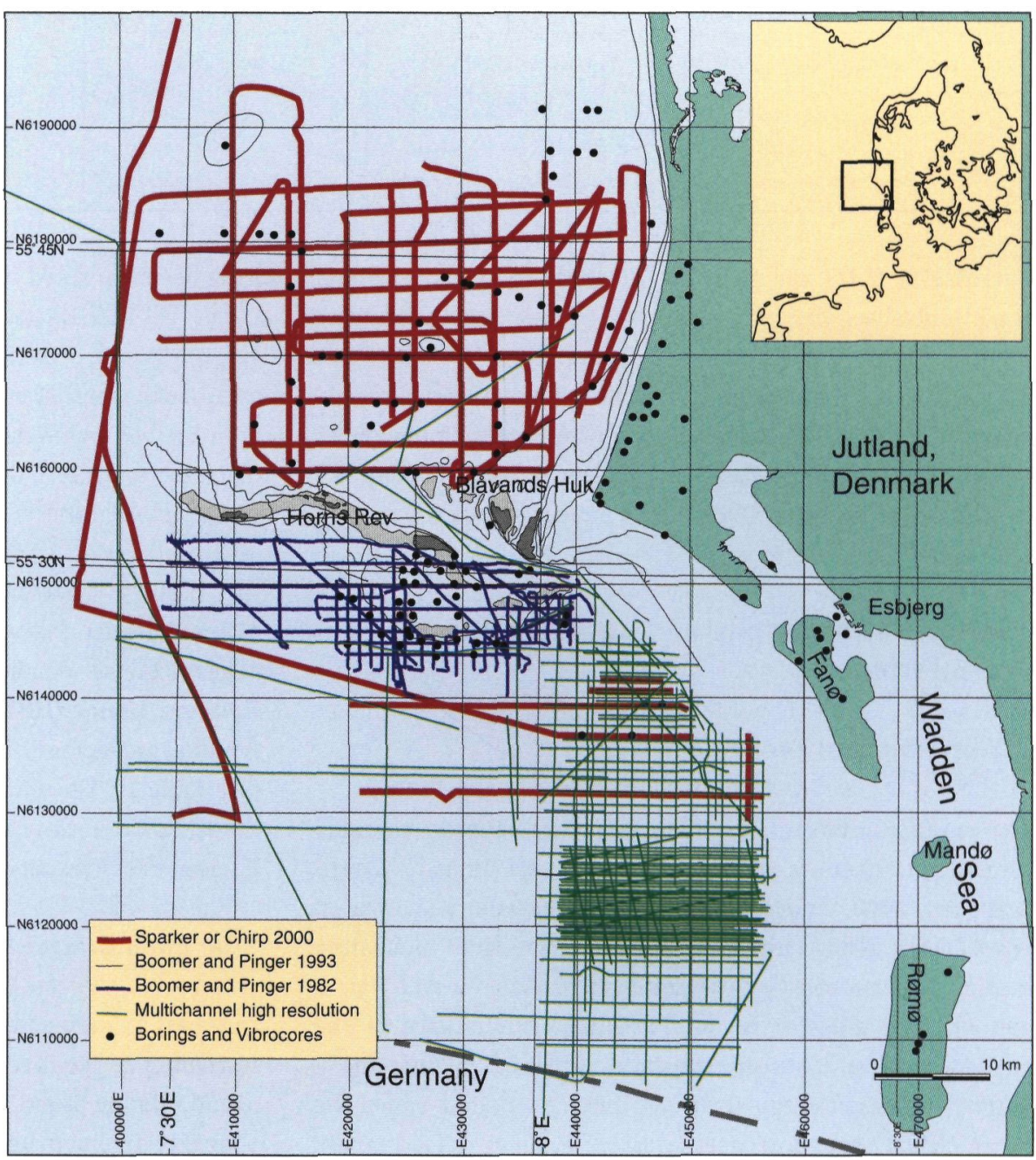




\begin{tabular}{|c|c|c|c|}
\hline $\begin{array}{l}\text { Seismic markers and } \\
\text { sedimentary units }\end{array}$ & Lithology & Environment & Age \\
\hline & Sand & Aeolian/onshore & \multirow{5}{*}{ Transgression $8800 \mathrm{BP}$} \\
\hline Marine Holocene (HM) & Sand & Marine & \\
\hline Base Holocene reflector $A$ & & Erosion & \\
\hline $\mathrm{HL}$ & Peat and silt & Freshwater and terrestrial & \\
\hline Base Holocene reflector $A$ & & Major erosion & \\
\hline WS in valley & Meltwater sand & Glaciofluvial & \multirow{4}{*}{ Weichselian } \\
\hline Horns Reef Valley & & Erosion & \\
\hline WS & Meltwater sediments & Glaciofluvial & \\
\hline Reflector top Eemian & & Erosion & \\
\hline Eemian (Eem) & Silty clay to silty sand & Marine & \multirow{2}{*}{$\begin{array}{c}\text { Eemian } \\
\text { Transgression }\end{array}$} \\
\hline Reflector B (EL) & Sandy peat & Freshwater and terrestrial & \\
\hline & & Erosion & \multirow{6}{*}{ Saalian } \\
\hline Upper Saalian Meltwater unit (SM) & Meltwater sand & Glaciofluvial & \\
\hline Reflector C & & Erosion & \\
\hline Upper Glacial unit (SG III) & Glacial deposits & Glacial & \\
\hline Lower Meltwater Unit (SM I) & Meltwater sediments & Glaciofluvial & \\
\hline Reflector C & & Glacial erosion? & \\
\hline LDGU / Lower Glacial unit (SG II) & Clay, silt, finesand and till? & Glacial deformation & (Early Miocene and younger) \\
\hline
\end{tabular}

Table 1. A list of the seismic/lithologic units recognised in the area and placed in a stratigraphic framework.

database at GEUS and from the literature. Selected shells of marine bivalves were ${ }^{14} \mathrm{C}$-dated by AMS at the Institute of Physics, Aarhus University or the University of Uppsala. Dates on marine shells are corrected for marine reservoir age by 400 years and calibrated to calendar years according to Stuiver et al. (1998). The dates are listed in (Larsen \& Leth, 2001b). All depths are meters below DNN (Danish ordinance datum $=$ map 0 ). UTM coordinates are in zone 32.

\section{Seismic stratigraphy and stratigraphic correlation}

\section{Stratigraphy of the region}

The pre-Quaternary of the study area is composed of undeformed tertiary strata probably of Miocene age (Huuse \& LykkeAndersen, 2000; Andersen, 2004). The Quaternary succession is seismically divided into two major sequences by an undulating erosional unconformity called reflector C (Table 1 and Figs. 3 and 4). This reflector is correlated with the surface of the Saalian bakke- $\varnothing$ landscape onshore. Offshore is reflector C defined as being the top of the Quaternary sequence called the lower glacial sequence. West of $8^{\circ} 00^{\prime} \mathrm{E}$, three seismic units have been discerned in this sequence: Lower Meltwater (SM I), Lower Till (SG II) and Upper Till (SG III) (see Table 1 and Fig. 3). East of $8^{\circ} 00^{\prime} \mathrm{E}$ and south of $55^{\circ} 30^{\prime} \mathrm{N}$ in the Fan $\emptyset$ Bugt area, sediments that are deformed by glaciotectonic deformation are observed below reflector $C$. This unit is called the Lower Glaciotectonically Deformed Unit (LDGU) (Table 1 and Fig. 3).

Reflector C forms a basin (a synform) (Figs. 3, 4), about 30 $40 \mathrm{~km}$ wide, west of the onshore Saalian bakke-ø landscape. In this basin a succession of seismic/morphogenetic units are defined: Upper Saalian Meltwater (SM), Eemian Interglacial deposits (Eem), Weichelian Meltwater (WS), Holocene (HL) and Holocene Marine (HM), that are separated by erosional unconformities (reflector B, Top Eemian and base Holocene reflector A) (see Table 1). The marine forelands and Horns Rev are parts of the HM unit in the basin. Onshore, the HM unit is capped by Holocene aeolian deposits or marsh deposits (Fig. 4).

\section{The lower glacial sequence in Fanø Bugt (LDGU)}

This unit is defined as the folded and thrusted sedimentary succession in the Fanø Bay area (Fig. 5). It can be traced down to $200-360 \mathrm{~m}$ below sea level, and it is bounded at its base by a weakly inclined décollement surface dipping 0.5 degrees 


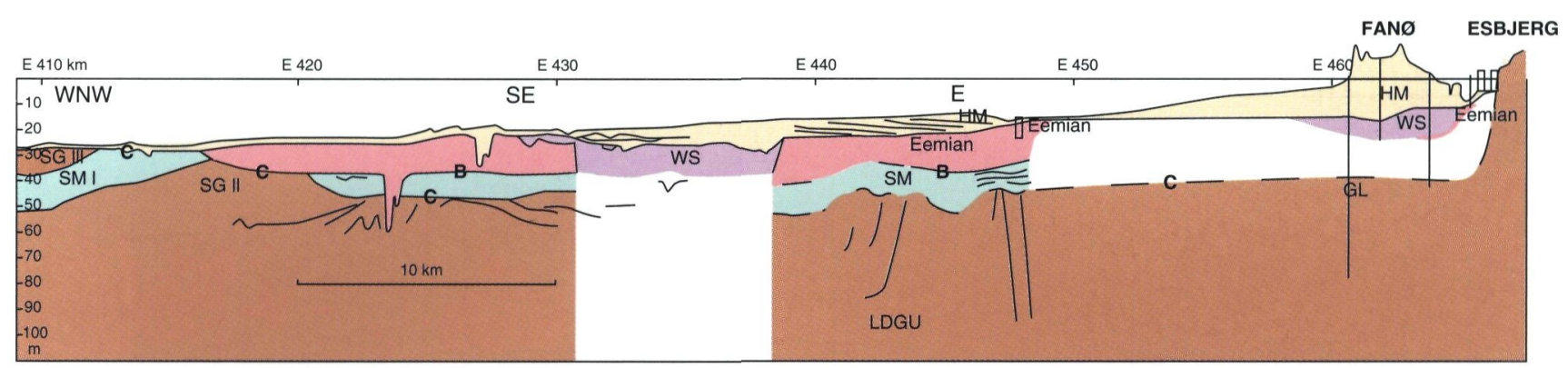

Fig. 3. Geological profile south of Horns Rev from the Saalian cliff and the Eemian shoreline at Esbjerg westward to Vovov Bakkeø, (see Figs. 1 and 9 for track line). The lower glaciotectonically deformed unit (LGDU) is recognized east of E: $438 \mathrm{~km}$. It may contain the lower glacial till unit SG II, which is covered by SM I and SG III. The top of LDGU, SG II, SM I and SG III is interpreted as a glacial erosion surface and is marked C. GL is Miocene clay found in a boring, probably dislocated like the LGDU. B represents an erosional surface separating the upper Saalian meltwater SM and the Eemian. WS is Weichselian meltwater deposits. HM is Holocene marine sands and aeolian sands on Fanø (see also Table 1 for stratigraphic overview).

towards WSW. Dimensions of the individual thrust sheets vary from less than $100 \mathrm{~m}$ to around $1.5 \mathrm{~km}$ on dip lines and extend for several $\mathrm{km}$ on strike lines. Often these huge thrust sheets of sediments seem only to have been moderately tilted or folded as they were transported along the thrust-faults (see the section with no vertical exaggeration on Fig. 5). Overall, the thrust complex has been observed in an area of 15 by $40 \mathrm{~km}$ in the Fanø Bugt. The western limit of the large-scale deformation is a north-south striking deformation front situated ca. $35 \mathrm{~km}$ from the west coast of Jutland, southwest of Esbjerg (Fig. 6). The eastern limit has not been detected. The direction of transport of the thrust sheets is towards the west and the west-southwest.

Using industrial lines, seismic correlation with well S-1 in the Danish North Sea sector (Lauersen, 1995), suggests that the décollement surface is located in the early Miocene Arnum Formation (Andersen, 2004.). The deformed sequence thus comprises sediments of Miocene to Quaternary age resting on undeformed tertiary layers; therefore, it is interpreted as being of glaciotectonic origin (Huuse \& Lykke-Andersen, 2000; Andersen, 2004). A correlation to onshore suggests that the deformation took place during a westward advance stage of the Late Saalian (Warthe) glaciation (Andersen, 2004.). This inference is based on comparison of direction, dimension, and style of deformation. The timing of the deformation will be discussed in more detail below.

The upper boundary of the LDGU is an unconformity (reflector C), which has been mapped in the Fanø Bugt area (see Fig. 6). The mapping was hampered by the first water multiple in major parts of the area. The unconformity surface is varying $\pm 10 \mathrm{~m}$ around the $-50 \mathrm{~m}$ contour. The topography expresses a hilly landscape with shallow valleys and small erosional basins. Some of the hills are clearly related to the expression of the underlying structures. A shallow valley trending E-W, with an irregular longitudinal profile, is incised in the central part of the study area. The eastern part of this valley is a deep (more than $138 \mathrm{~m}$ below sea level) tongueshaped basin (Fig. 6).
In a distinctly more shallow area to the south, the deformed strata are situated just below the seabed, with only a thin cover of younger sediment. The long axis of this elevated area is nearly parallel to the strike of the thrust sheets. The crest of the elevation is the recent 'Røde Klit Sand' bank, where stones on an abrasion platform suggest that glacial tills exist near the seafloor (Jarke, 1956). The mapped surface (reflector C) is interpreted as being a glacial erosional unconformity of Saalian age (Table 1).

\section{The lower glacial sequence west of $8^{\circ} 00^{\prime} E$ (SG II, SM I, SG III)}

The deposits of the lower glacial sequence west of the deformation front (Fig. 6) have mainly been investigated using single channel seismic data. The sequence can be divided into a lower unit (SG II), an intermediate unit (SM I) and west of $7^{\circ} 39^{\prime} \mathrm{E}$ an upper unit (SG III) (Fig. 3 and Table 1).

\section{The lower unit (SG II)}

The seismic expression of the lower unit is chaotic, folded or dislocated (Fig. 7A) and may indicate a glacial disturbed unit, possibly a till. The top of SGII is sloping westwards in the area southwest of Horns Rev and is conformably overlain by the intermediate unit (Fig. 3).

\section{The intermediate unit (SM I)}

SM I is a $15 \mathrm{~m}$ thick unit, characterized by a distinct parallel reflection pattern with high continuity (Fig. 7b, Fig. 3 west of 415.0). It is dipping ca. $6 \mathrm{~m} / \mathrm{km}$ towards WNW. The unit extends at least $14 \mathrm{~km}$ north of the profile in Fig. 3 (see Fig. 1) and continues below the western Horns Rev between the Vovov and Tuxen shoals. It may, according to Kuijpers (1995), crop out on the northwest flank of Horns Rev. It has not been sampled with certainty but probably consists of relatively fine-grained meltwater deposits. 


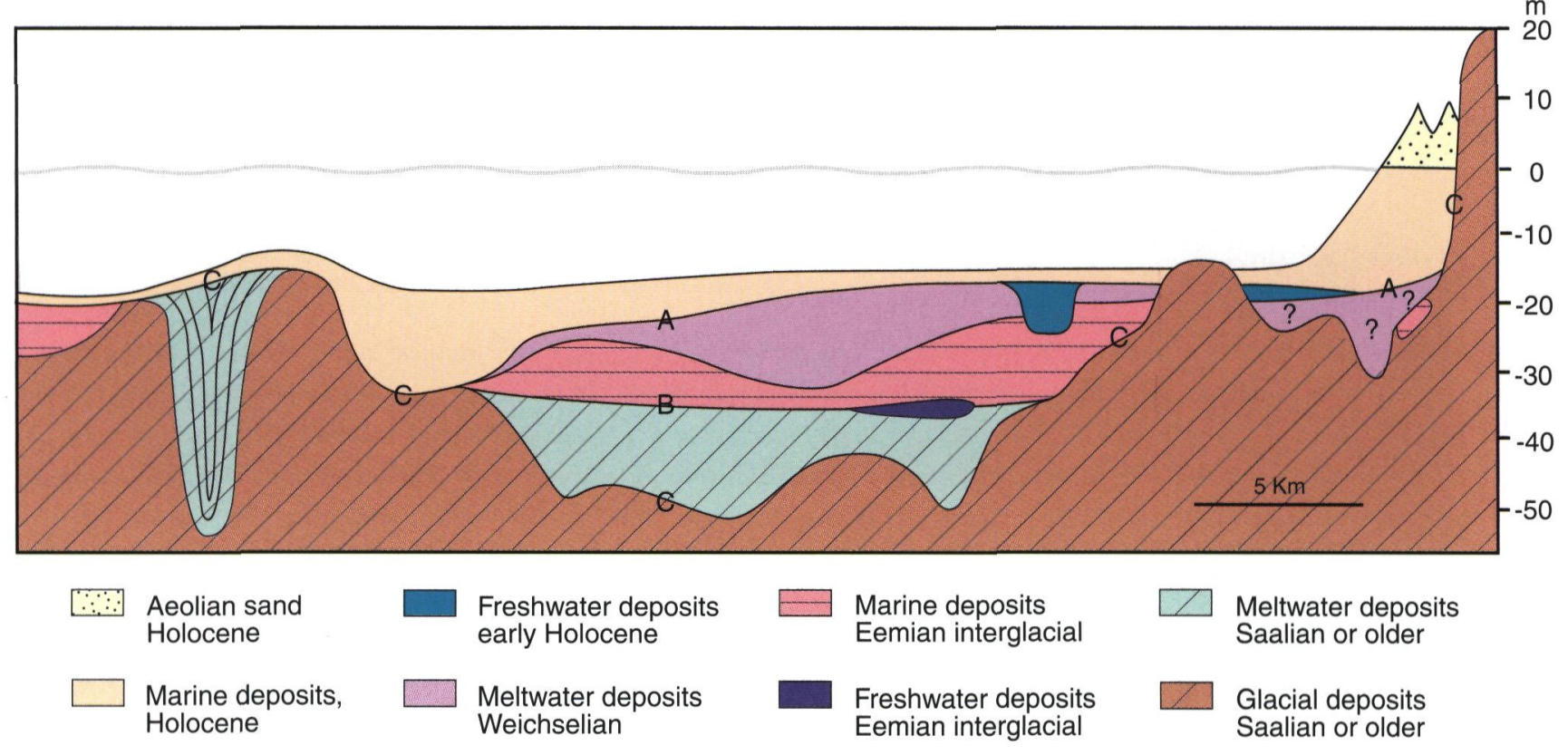

Fig. 4. Schematic E-W cross-section across the wide basin in the Saalian landscape north of Horns Rev (approx. $55^{\circ} 45^{\prime} \mathrm{N}$ ).

\section{The upper unit (SG III)}

The seismic expression of the upper unit is chaotic on the scale of a few meters, but often it shows small-scale hummocky clinoforms and subhorizontal reflectors (Fig. 7A). The unit seems to be less homogenous and more structured than a typical diamicton-dominated sequence (Stewart and Stoker, 1990). The SG III unit is more than $30 \mathrm{~m}$ thick, hence it is hardly a single till bed but rather a mosaic of glacial and meltwater deposits. It may have been dislocated by ice or sliding on a scale of $1-100 \mathrm{~m}$. Dislocations, which cut through the base of the unit, have not been recognised. Based on very sparse seismic lines it is supposed that SG III forms the surface of an erosional platform at ca. $20 \mathrm{~m}$ depth, forming a bank that can be traced to ca. $30 \mathrm{~km}$ north of the western Horns Rev (see Fig. 1). The till may crop out a few $\mathrm{km}$ west of Horns Rev (Kuijpers, 1995) and about $20 \mathrm{~km}$ north of Horns Rev (ca. $55^{\circ} 45^{\prime} \mathrm{N}$ and $7^{\circ} 27^{\prime} \mathrm{E}$ ). The relatively high area (Fig. 8) of glacial deposits west of Horns Rev is here called Vovov Bakke- $\emptyset$. About $18 \mathrm{~km}$ north of Horns Rev the bakke- $\varnothing$ area is cut by an E-W trending valley, up to $2 \mathrm{~km}$ wide and $80 \mathrm{~m}$ deep, which is filled by acoustically conformably layered sediments (Fig. 4).

The unconformity (reflector $\mathrm{C}$ ), which truncates the top of the LDGU, seems to continue as an erosion surface on top of SG II, SM I and SG III (Fig. 3). Further north and west, it forms the base of the Horns Rev deposits east of $7^{\circ} 30^{\prime} \mathrm{E}$, and is outside the reef only covered by a few meters of Holocene sediments (Fig. 8). Reflector C may be correlated with the interpretation of Foged (1987) who followed a clear reflector, which he interpreted as 'top Saalian glacial deposits' westward to about $104 \mathrm{~km}$ from the coast at Henne Strand (Fig. 1).

\section{The old Saalian landscape onshore (bakke-ø (andscape) and its extension offshore}

Onshore in western Jutland, the Saalian landscape is strongly modified by solifluction and stream erosion and forms the surface of the so-called bakke- $\emptyset$ landscape. The surface of this landscape, in the coastal area, is mostly $20-30 \mathrm{~m}$ high (Fig. 8). The bakke-ø landscape is close to the recent coastline between Henne Strand and Nymindegab (Fig. 1). About $5 \mathrm{~km}$ seaward, extensive abrasion platforms eroded into glacially deformed tills (Huuse \& Lykke-Andersen 2000 and the present survey) have been found near $-17 \mathrm{~m}$ (Fig. 8). They are regarded as eroded extensions of the Varde Bakke- $\varnothing$ (Fig. 9). Uncertain indications of a valley filled with conformably layered sediments have been observed between these platforms and the coast off the Filsø area (Fig. 1).

The glacial landscape constitutes most of the eastern coast of the Wadden Sea in the area around Esbjerg. The seaward continuation of the undulating surface of the Saalian landscape forms a wide depression to about $50 \mathrm{~m}$ below sea-level between the onshore Saalian landscape and Vovov Bakke- $\varnothing$ (Fig. 4). The depression has the same level below sea-level as the submarine glacial landscape in the Fanø Bugt area (compare Figs. 4 and 6) and extend northward to at least $55^{\circ} 50^{\prime} \mathrm{N}$. A buried slope from $25 \mathrm{~km}$ north of Blåvands Huk to southeast of Esbjerg (Fig. 8) marks the eastern limit of this large depression, providing the accommodation space, which mainly controlled sediment deposition since late Saalian time. The meltwater deposits described below constitute the oldest deposits of this basin. 

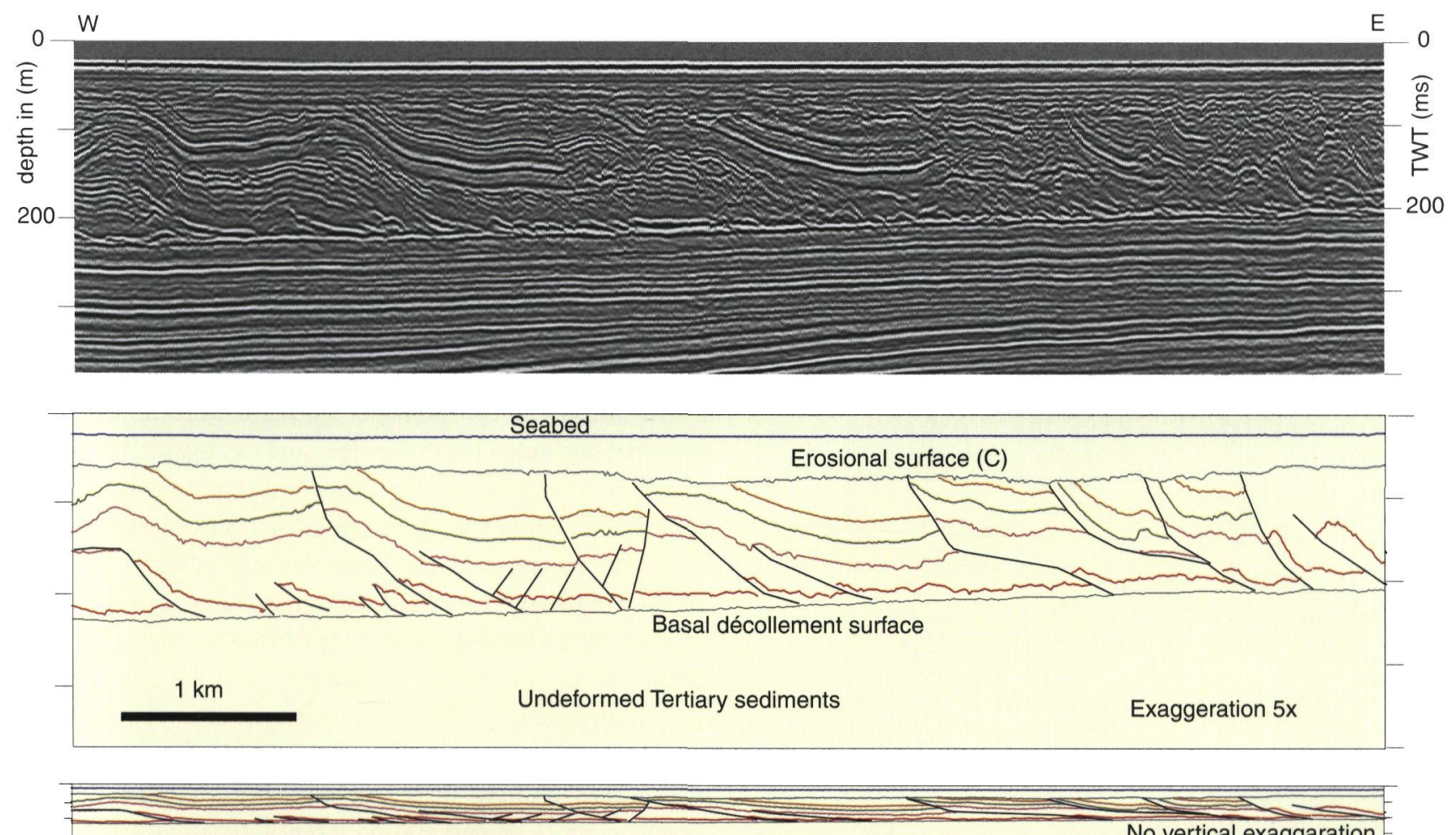

No vertical exaggaration

Fig. 5. An E-W striking seismic profile from the Fanø Bugt illustrating the lower glaciotectonically deformed unit (LDGU) (see Fig.1 for position). The profile reveals a series of thrust-sheets sliding on a $0.5^{\circ}$ westward dipping basal décollement. The section is almost a dip-section and suggests glaciotectonic deformation with a transport direction towards the west. The deformed sequence comprises Miocene and Quaternary sediments. An erosional surface (reflector $C$ ) truncates the folded and thrusted sequences. This has been mapped in Fig. 6 .

\section{The Upper Saalian Meltwater Unit (SM)}

The erosion surface (reflector $\mathrm{C}$ ), outside the bank areas, is covered by a 10 - $20 \mathrm{~m}$ thick layer (SM) (Figs. 3, 4 and 10) showing a chaotic reflection pattern comprising parallel and hummocky clinoforms (Fig. 10). In the deepest, central part of the basin mentioned above, the SM unit covers the undulating surface of reflector C (Figs. 3 and 4). Twelve metres of fine to medium sand with sparse gravel and lignite grains have been sampled in the unit in a few boreholes at Horns Rev (Fig. 11). The surface of SM (reflector B, Table 1) is, with some exceptions, situated below $-35 \mathrm{~m}$ DNN. It post-dates reflector $\mathrm{C}$, which predates the Eemian, and probably corresponds to the top of the Saalian moraine landscape. Hence SM is interpreted to be late Saalian glaciofluvial sediment. The unit may locally include glacial till. The age relation between SM and SM I (Table 1 and Fig. 3) is not clear. A few channels have been incised into the surface of the unit and were subsequently filled before the Eemian sequence was deposited (Fig. 3). Petrographic analysis of 4 gravel samples from Horns Rev, that is probably sourced from these glacial deposits, demonstrated that more than two thirds of the grains $>4 \mathrm{~mm}$ are flint or limestone, a composition that resembles late Saalian meltwater deposits onshore (Skibsted, 1992).

\section{The Eemian (Eem)}

The internal seismic signature of Eem is remarkably devoid of reflections and looks very homogenous and transparent on the seismic records, (Fig. 7c). Based on core data it is assumed that the sediments are mostly silty clays and sandy silt and very homogenous due to bioturbation. Eemian deposits, up to $13 \mathrm{~m}$ thick, have been identified 20 to $35 \mathrm{~m}$ below the present day sea level in an area delineated on Fig. 9. The Eemian has been identified in the boreholes by the presence of the foraminifer species Elphidium lidoense and/or Elphidium tranluscens (Konradi et al., 2005). The top of Eem is mostly erosional and locally it almost merges with the surrounding surface of the Saalian (Fig. 3). It is often a fairly strong and flat reflection below Weichselian or Holocene deposits (e.g. Fig. 7c) showing a few channels cut into the Eemian deposits (Fig. 3). Regionally the top Eemian reflection slopes gently westward (Fig. 9). In the early surveys (DGI 1982) of the Horns Rev area it was often the only reflection that could be observed below the Holocene.

\section{The Weichselian (WS)}

The internal seismic signature of unit WS is characterised by short wavy reflections and hummocky clinoforms. The unit 


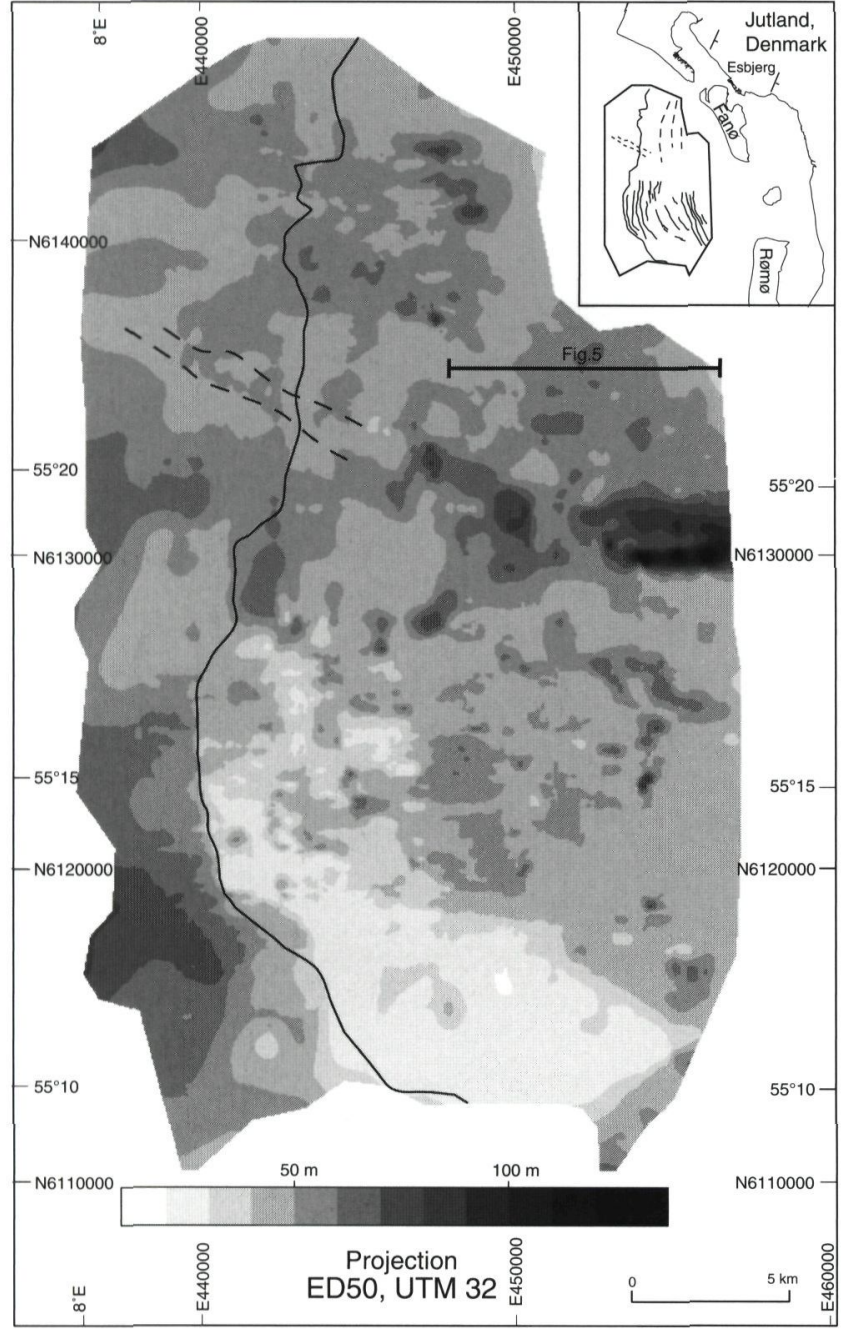

Fig. 6. Relief on the erosional surface on top of LDGU and its westward extension (Reflector $C$ ) in $m$ below sea level. The line marks the approximate western limit of the dislocations below this surface. Contour spacing is $10 \mathrm{~m}$ based on a velocity of $1500 \mathrm{~m} / \mathrm{s}$ in the sediments. Insert map shows the strike of thrust sheets in the mapped area and around Esbjerg.

appears fairly dark on the seismic records. The thickness is in the range of $3-11 \mathrm{~m}$. The internal reflectors probably mirror small-scale channels and shallow lakes. A few cores suggest that the sediments are fine and silty sand often laminated with dark organic particles. The unit predates the Holocene marine deposits and overlies the Eemian north of the Inner Horns Rev and west of the abrasion platforms in the Saalian tills west of Varde Bakke- $\varnothing$ (Fig. 9). The surface of the unit (reflector A) seems to be erosional in most of the area with depths between 16 and $22 \mathrm{~m}$. The boundary to the overlying marine sediments is not distinct on the seismic records in these areas. The erosional surface reflector A probably continues as an extension of the erosional level on top of the abrasion platforms in the Saalian tills (Fig. 4).

In the deeper, western part, the thickness of WS decreases to less than $5 \mathrm{~m}$ and pinches out towards a buried valley along the base of Vovov Bakke- $\varnothing$ (Figs. 4 and 8). On the valley floor only erosional remnants are seen at depths of 28 to $36 \mathrm{~m}$. The limit of the unit towards the south and southwest is often a few meters high edge, suggesting erosion of the Weichselian deposits (WS on Fig. 10). Erosion is especially extensive in the more shallow areas near shore where Saalian- and Eemian deposits often directly underlie Holocene deposits (Figs. 8 and 10).

From the general slope of the seabed it is likely that the Weichselian deposits are the remnants of a distal alluvial cone mostly fed from north-east from the Skjern River system outlet (arrow Fig. 8). The upper metres of the unit are clearly modified by subsequent erosion and re-deposition in the latest Weichselian and early Holocene. Surprisingly, meltwater deposits related to the Varde and Kongeå outlets (Fig. 8) have not been recognised in the Horns Rev area or in the Blåvands Huk - Skallingen area. Weichselian meltwater sediments have been observed below northern Fanø in wells (Fig. 3), but not below the central part of the island. It is possible that the river outlet at Varde (Fig. 8) was comparatively small, hence an alluvial cone never developed outside this outlet and the stream was running in a still unknown confined channel. Nevertheless, a major erosion event predating the marine deposition is indicated (Table 1).

\section{The Horns Rev Valley}

A buried valley about $5 \mathrm{~km}$ wide and $10 \mathrm{~m}$ deep has been mapped from near the southern end of Fanø $\left(55^{\circ} 21^{\prime} \mathrm{N}\right)$ to 20 $\mathrm{km}$ north of Horns $\operatorname{Rev}\left(55^{\circ} 40^{\prime} \mathrm{N}\right)$. The valley is cut into the glacial surface along the base of Vovov Bakkeø, passes below the Outer Horns Rev, and is therefore called the Horns Rev Valley (Fig. 8). The bottom is flat and cut down to at least $38 \mathrm{~m}$ below sea level, into or through Eemian deposits, down into Saalian deposits (Figs. 3 and 11). The valley is filled to ca. $28 \mathrm{~m}$ below sea level with fine to medium grained well sorted sands, occasionally with reworked shell fragments and lignite according to data from a few borings in the Horns Rev area. The valley was not completely filled in the early Holocene and small basins with peat are observed at the top of the fill of the Horns Rev Valley. The peat is dated by pollen as Early Holocene (DGI, 1982 and Fig. 11), hence the Weichselian age of the Horns Rev Valley is well established (Table 1).

\section{Base Holocene and the transgression (reflector $A, H L$ and $H M$ )}

An erosional surface situated $20-30 \mathrm{~m}$ below present day sealevel forms the base of the Holocene marine deposits (reflector A, Table 1). The surface extends eastward several kilometres below the onshore coastal areas as well as below the northern Wadden Sea (Fig. 8). Outside the Saalian deposits, this very flat surface has been cut into Eemian marine deposits or into Weichselian meltwater and other deposits (e.g. Figs. 10 and 11). 

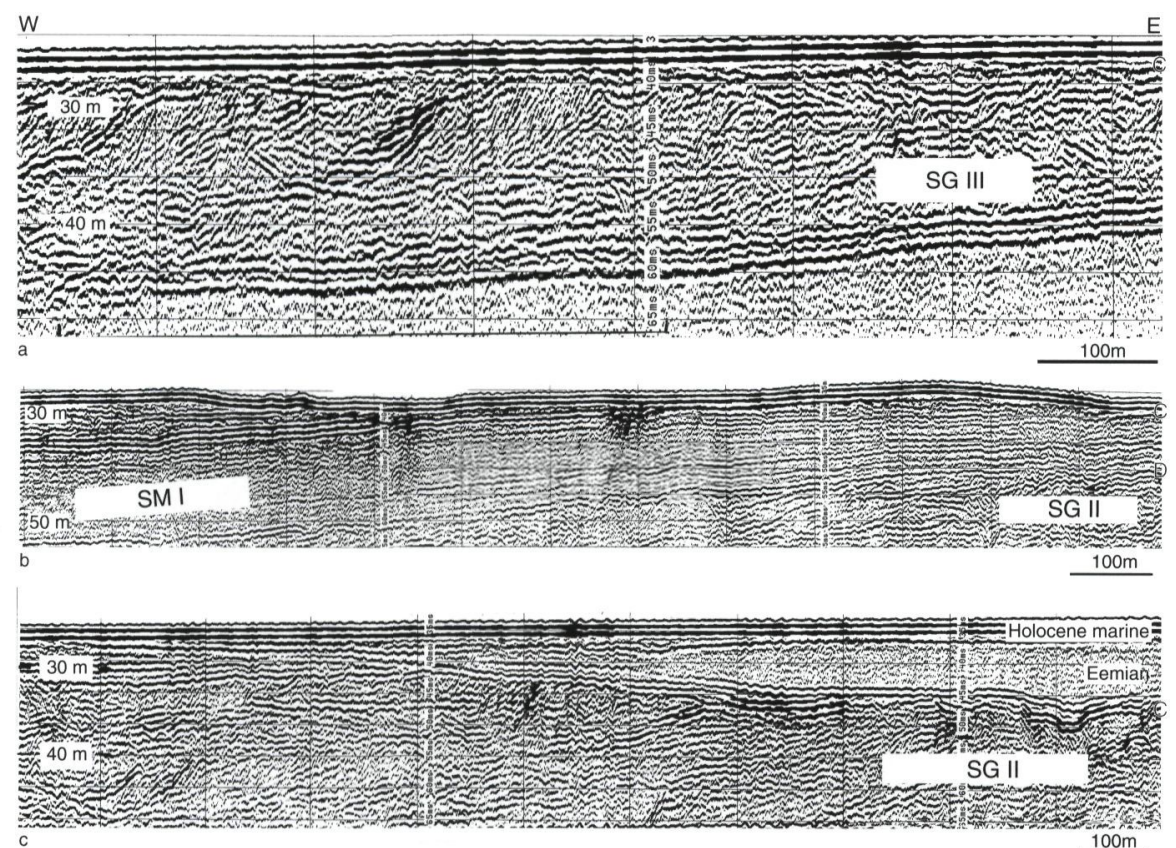

Fig. 7. Sparker records of the glacial sequences west of the dislocated units (LDGU). a. Shows the upper till unit (SG III) resting on the lower meltwater unit (SMI). b. Shows the lower meltwater unit (SM I) with better resolution. c. Shows lower till unit (SG II), which is partly covered by the homogenous looking marine Eemian which onlap the glacial deposits towards the west. Small limnic/mire deposits probably occur at the base of the Eemian. On top of all profiles is a ca. $2 \mathrm{~m}$ cover of Holocene marine sand. The profiles are situated southwest of Horns Rev (Fig.1) along the profile in Fig. 3: UTM E: 410 to $E: 420 \mathrm{~km}$.
Thus, a major accommodation space was available for sedimentation as the sea transgressed the area in early Holocene time. The surface is locally covered by fine terrestrial sands, small freshwater basins, fluvial deposits and soils developed in late Weichselian and early Holocene times (Table 1, HL), where inundation took place over a fairly flat and sheltered landscape (Fig. 8). In the reef area of Horns Rev Valley, bogs and lakes were inundated at a level now $31 \mathrm{~m}$ below sea level, which initially led to the formation of brackish lagoons. On the flanks of the valley a similar development about $25 \mathrm{~m}$ below present day sea level has been documented by foraminifers, diatoms and dated by pollen to very early Atlantic time (approximately $8800 \mathrm{BP}_{\text {cal }}$ ) (reports by H. Krog and K.L Knudsen in DGI, 1982). At this time, the eustatic sea level was rising fast (Nielsen et al., 1995; Krog, 1979; Streif, 2004) and relative sea level reached $-3 \mathrm{~m} \mathrm{DNN}$ in the area about $7000 \mathrm{BP}_{\text {cal }}$ (Clemmensen, 1999). Since $5000 \mathrm{BP}_{\text {cal }}$ the relative sea level has, with small $(<1.5 \mathrm{~m})$ fluctuations, been near the present (Krog, 1979) and the study area has probably been subsiding about $0.35 \mathrm{~m} / 1000$ years (Nielsen et al., 1995). Hence, the coastal processes have been working at nearly the same level for a long time.

\section{The geological development in the Holocene}

The rise of sea level resulted in re-establishment of the sedimentary basin illustrated on Fig.8, including extensive areas that are now land. Sediment, mostly sand, was supplied through coastal transport from the north creating the conditions for development of a major spit complex. Another important sediment source to the area is material transported within the seabed from west and south. However, only the geological development will be discussed here, as the dynamic and environmental development of the Holocene marine deposits will be reported elsewhere.
The coastal system

According to recent estimates (by the Danish Coastal Protection Board) some 2.5 million $\mathrm{m}^{3}$ of sediment are supplied annually to the system from the north, of which ca. 1 million $\mathrm{m}^{3}$ is transported away to Fanø and the Wadden Sea area (Kystdirektoratet, 2001). The coast south of Ringkøbing Fjord is presently aggrading about $0.5-2 \mathrm{~m} /$ year, this is in contrast to the long stretch of coast north of the study area where net erosion takes place (Kystinspektoratet, 1998; Leth et al., 2004). The cape of Blåvands Huk is separating the southern end of the wave-dominated, microtidal, simplified west coast of Jutland and the northern limit of the mesotidal Wadden Sea (Fig. 1). The Blåvands Huk forms the centre of an, in plan view, inverted T-shaped sand accumulation approximately $25 \mathrm{~km}$ long, $30 \mathrm{~km}$ wide and $15-25 \mathrm{~m}$ thick containing in the order of $7.5 \mathrm{~km}^{3}$ marine and derived aeolian sediments. The entire volume has been deposited in Holocene time (Larsen \& Leth, 2001b). Consequently, about 1 million $\mathrm{m}^{3}$ of sediment has, on average, been stored annually in the area since the sea level approached the level of the present day. The extension of the marine foreland is shown in Fig. 1.

The development of the marine foreland from 10000 to $5000 \mathrm{BP}_{\text {cal }}$ is not well known due to a $5-10 \mathrm{~m}$ thick cover of wind blown sand, especially in the Kallemærsk Hede area, and tidal deposits in Ho Bay (Fig. 1). Most of the deposition in that period, took place in environments sheltered by barriers such as lagoons, on tidal flats and channels like in Ho Bay today, in lakes dammed by the littoral deposits and the Saalian landscape or in the form of large dunes and cover sands (Clemmensen et al., 1996; Clemmensen, 1999).

Radiocarbon dates suggest that a rim of the north-eastern part of the marine foreland and Ho Bay, more than $3 \mathrm{~km}$ wide, was built out from the Saalian cliff and up to near sea-level 


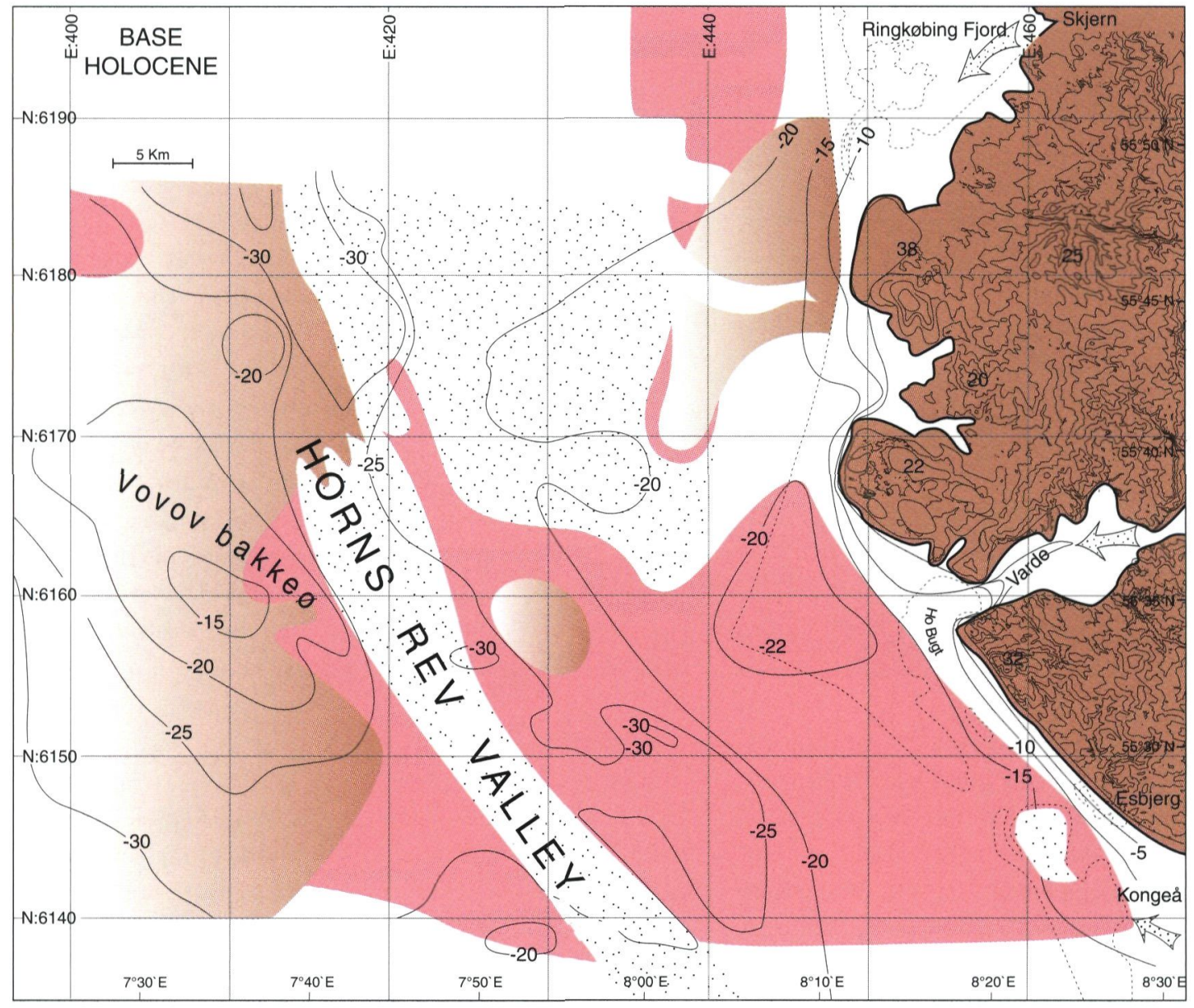

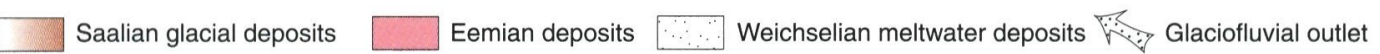

Fig. 8. Map of the topography at the base of the Holocene with $5 \mathrm{~m}$ between the curves and subcrop geological map. The uneven morphology to the east represents the surface of the old Saalian landscape ("bakke- $\left.\varnothing^{\prime}\right)$, but with the aeolian cover removed. Note the marked slope from the bakke-ø landscape down to the flat surface about $-20 \mathrm{~m}$ DNN (Danish ordnance datum). The onshore part is based on topographical maps and borings while the offshore part is based on seismic interpretation verified by borings and geotechnical CPT-soundings. The arrows mark the major outlets of meltwater streams during the Weichselian glaciation.
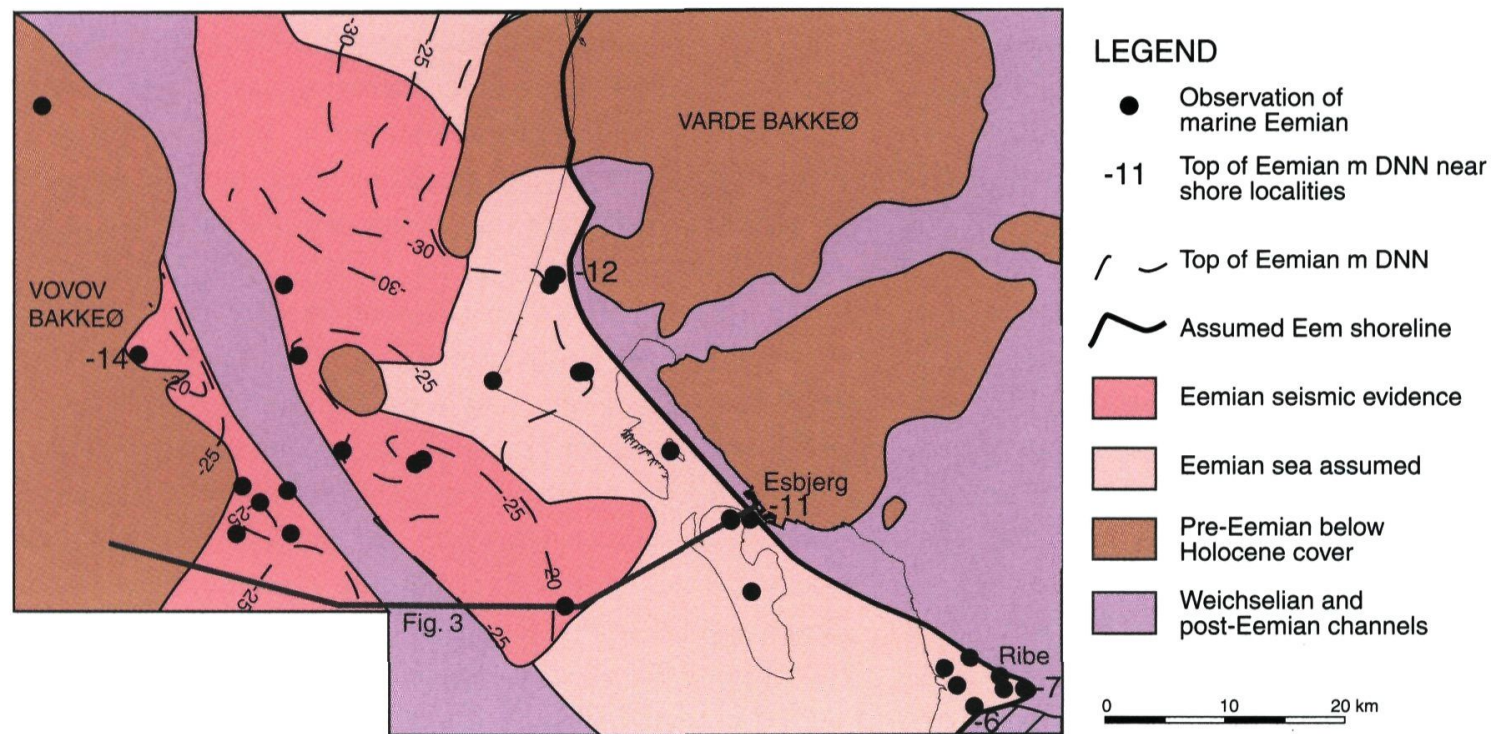

Fig. 9. Distribution of the marine Eemian and Pre-Eemian below the Holocene cover and Weichselian deposits. Position of Fig. 3 is marked west of Esbjerg. The offshore parts of the Varde and Vovov Bakke-ø were probably partly flooded during the Eemian sea level highstand. 


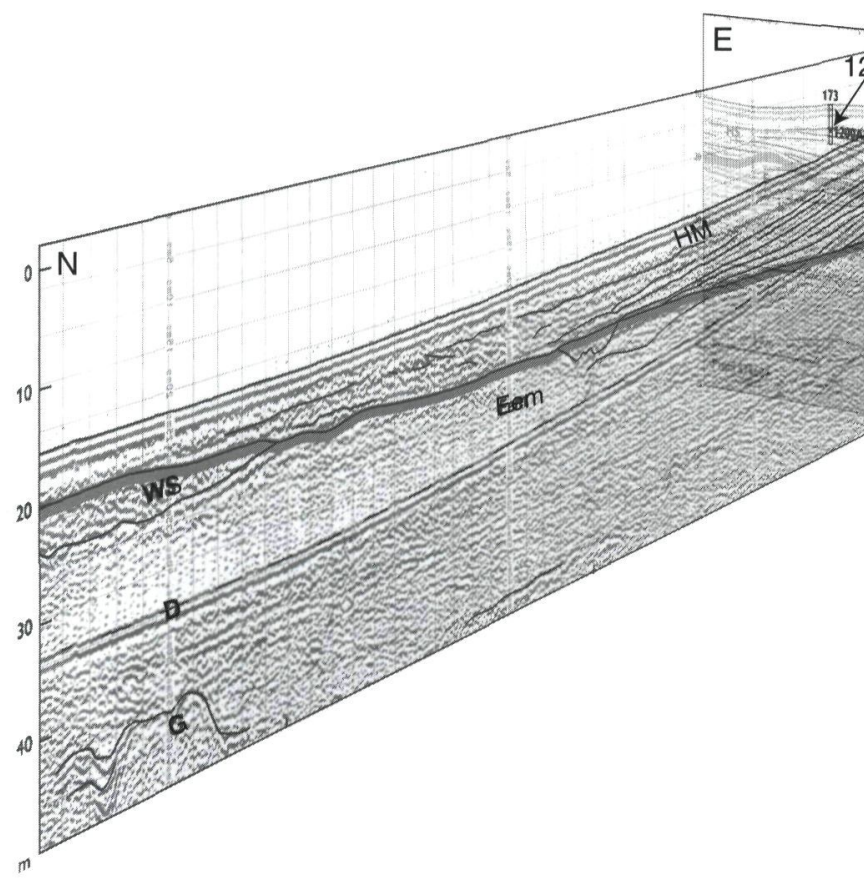

before $6800 \mathrm{BP}_{\text {cal }}$ (Davis et al., 1997). During the last 3000 years, a stretch of $25 \mathrm{~km}$ of the coast south of Ringkøbing Fjord, has prograded 1 - $3 \mathrm{~km}$ towards the west to form a barrier ridge system (Jessen, 1925; Petersen, 1998; Nielsen et al., 1995) concurrent with the outbuilding of the associated shoreface down to a depth of about $15 \mathrm{~m}$ (Fig. 12).

The $15 \mathrm{~km}$ long, southeast trending Skallingen peninsula is a post- $1600 \mathrm{AD}$ analogue to a barrier island with tidal sedimentation on the northeast side (Aagaard et al., 1995). The southeast coast of Skallingen is now retreating (Jessen, 1925; Aagaard et al., 1995), but probably in the order of 1 million $\mathrm{m}^{3}$ sand is transported along the lower shoreface, deposited and dredged in the mouth of the tidal channel north of Fanø (Kystdirektoratet 2001).

\section{The Inner Horns Rev}

A $6 \mathrm{~km}$ wide sandbank, the Inner Horns Rev (Fig. 1), protracts $16 \mathrm{~km}$ into the North Sea to the west of Blåvands Huk. The bank area is freely exposed to high-energy waves of the North Sea, and is situated at right angles to the main direction of the tidal wave (Brockmann et al., 1981). The shallow sandbank is traversed by three tidal channels (Fig. 1). The south slope toward the channel Slugen is steep, while the northern slope is more gentle and may be regarded as a continuation of the outer shoreface of the coast, modified as tidal deltas related to the crosscutting channels. The bank is a highly dynamic area with active sand-accumulation. The geology of the northwestern part of the bank is illustrated in Fig. 10. In spite of the waves and the strong tidal currents across the complicated topography of the bank, the dated sediment structures suggest that the west end of the bank has been prograding some $3.5 \mathrm{~km}$ westward in the last 800 years. Seismic evidence suggests
Fig. 10. Sparker profiles (800-1200 Hz) along and across the northern slope of the Inner Horns Rev. Tracks are shown in Fig. 1. The sigmoid/ oblique clinoforms indicate progradation towards the west of the bank concurrent with the outbuilding of the northern slope. The dating of the reflector marked $1200 A D$ is based on a $14 C$ dating of a shell in vibrocore 173. It is suggested that the bank has grown about $3.5 \mathrm{~km}$ in 800 years. The upper quasi-homogenous $4 \mathrm{~m}$ of the bank is frequently reworked based on ${ }^{14} \mathrm{C}$ datings. The grey line marks the base of the Holocene (reflector $A$ ). The marine Eemian and the upper Saalian meltwater unit (SM) wedge out toward glacial deposits (G) near the corner of the profiles. Glacial dislocation may be present below $50 \mathrm{~m}$ near the corner. (WS) is interpreted as Weichselian meltwater deposits. In most of the area the latter unit has probably been eroded before deposition of the Holocene sediments. (D) Denotes the water layer multiple.

concurrent sedimentation on the south- and the north-slope. In one borehole on the north-slope the net sedimentation rate has been calculated to be $5.1 \mathrm{~mm} /$ year since $1000 \mathrm{BP}$, and only $0.5 \mathrm{~mm} / \mathrm{y}$ before this period (Larsen \& Leth, 2001b). All these sediments seem to be sourced from coastal longshore sand transport from the north.

\section{The offshore system}

In the area north of Horns Rev, in the deep western part of the basin 20 - $30 \mathrm{~km}$ offshore (Fig. 8), the Holocene marine sediments (HM, Table 1) are $8-18 \mathrm{~m}$ thick. Seismically, the unit is characterised by mostly parallel oblique reflection patterns showing progradation toward the east to northeast, i.e. away from the Vovov Bakkeø. To the east the sediments onlap the slope of the Weichselian sediments or pinch out towards the northern extension of the channel called Slugen. The sediments thus fill a wide valley for a large part situated above the Weichselian Horns Rev Valley (Figs.4 and 8). The position of the buried spits and ${ }^{14} \mathrm{C}$ datings suggest, that a major part of the offshore sedimentation took place during the early transgression when relative sea level in the North Sea was lower (DGI, 1982) and that the sedimentation rate was moderate about 5000 BP (Larsen \& Leth, 2001a, b). After the valley was 


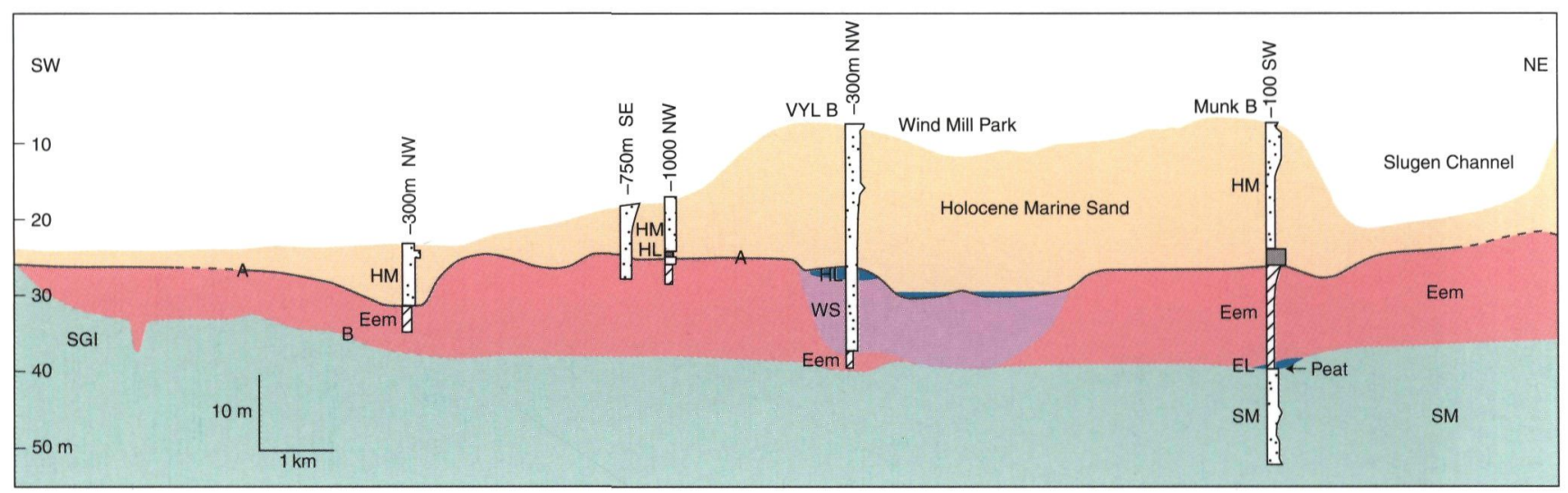

Fig. 11. Geological cross-section of the outer Horns Rev (see Fig. 1 for location). The Saalian deposits comprise mostly the upper meltwater unit, except for the lower till unit in the WNW-SW part of the profile, which is part of the profile Fig. 3 (and shown as seismic profile on Fig. 7c). The position of reflector $A$ is supported by many geotechnical soundings in the Wind Mill Park. Note the lack of Weichselian meltwater deposits outside the buried channel in the middle of the profile.

filled to 16 - $20 \mathrm{~m}$ below sea level, a $1-3 \mathrm{~m}$ thick bed of medium sand, occasionally with gravel, was deposited. Locally this bed forms a north-south trending shallow sandbank (along E $410 \mathrm{~km}$ on Fig. 1). Sediment transport from a west to south-westerly direction is indicated by the direction of progradation.

\section{Outer Horns Rev}

The east-west trending sandbank Outer Horns Rev (Fig. 1) and a buried spit located at $55^{\circ} 39^{\prime} \mathrm{N}$ modify the pattern described above. The reef, with depths less than $10 \mathrm{~m}$, is situated south of the channel Slugen and extends ca. $40 \mathrm{~km}$ westwards into the North Sea (Fig. 1). Very shallow sandy shoals with depths less than $4 \mathrm{~m}$ are situated both at the southern and northern edge of the major bank (Jessen, 1925; Lüneburg, 1967). Horns Rev west of the Vovov shoal (west of $7^{\circ} 35^{\prime} \mathrm{E}$ ) can be regarded as an accumulation platform on the south slope of Vovov Bakke- $\emptyset$, but the main part has accumulated on a flat erosional surface (Figs. 8 and 11). The southern lower parts of Horns Rev are a complex of gravel-rich spits that extend to the easternmost shoal, the Cancer bank (DGI, 1982; Kuijpers, 1993). Borings are only available from the central part of the reef including the Vyl and Munk shoals (Fig. 1). Here, well-sorted fine to medium marine sands are found. The sediment at the surface is mostly medium and coarse sand locally with fine

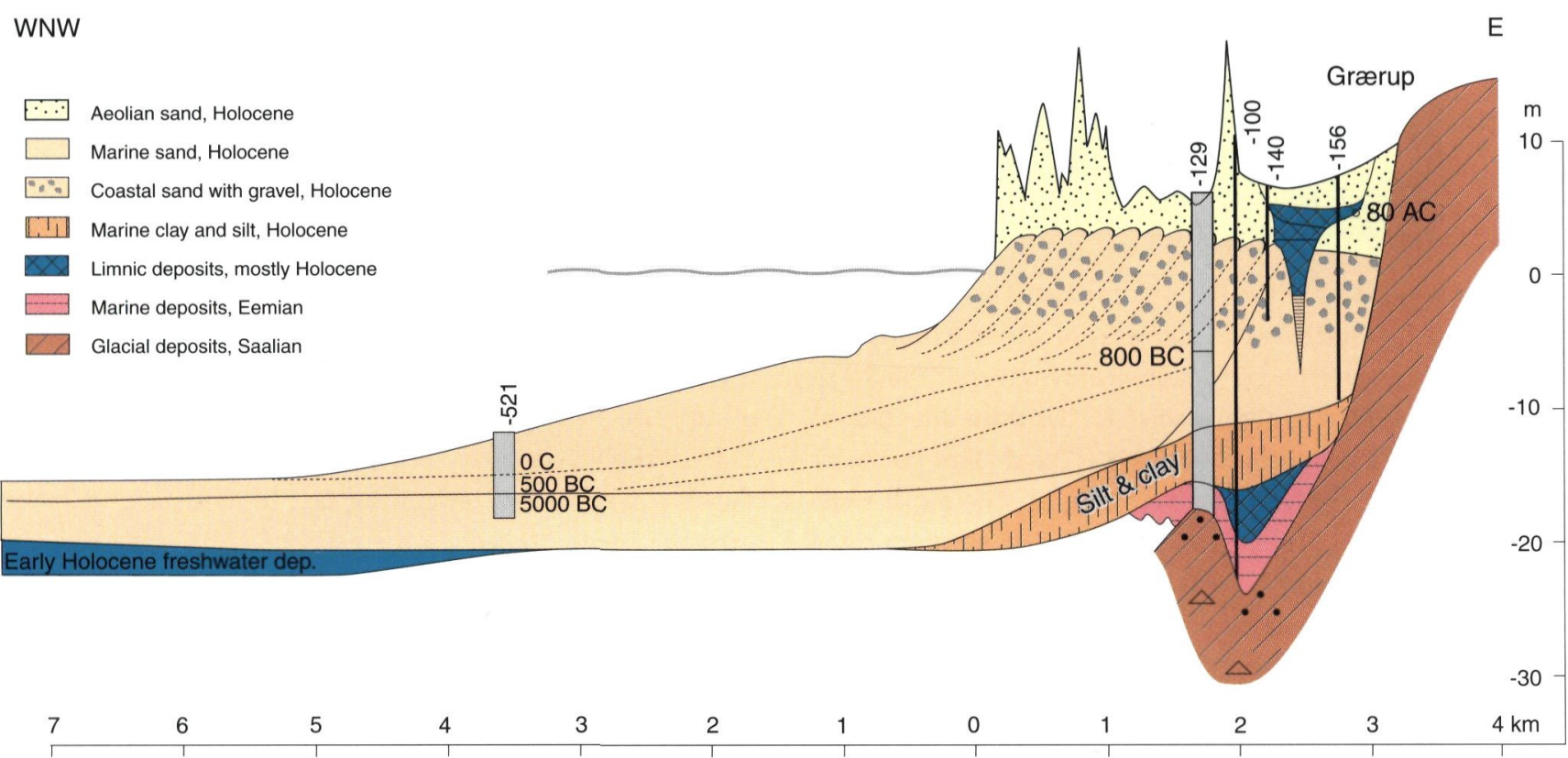

Fig. 12. Cross-section of the buried slope at Grærup, showing the marine foreland and the associated shoreface. The slope is older than the Eemian deposits at the foot of the slope. The onshore structures are based on borings (GEUS 120 archive numbers) and georadar (Nielsen et al., 1995). The suggested former position of the shoreface $(0-15 \mathrm{~m})$ is based on the assumption that the general form is constant outside the highly variable sandbars in the inner shoreface zone $(0-6 \mathrm{~m})$. The ${ }^{14} \mathrm{C}$ datings are calibrated calendar years. The $800 \mathrm{BC}$ date is from Petersen (1998). For location see Fig. 1. 
gravel. Most of the bank is acoustically homogeneous on the available seismic records. Prograding reflectors and the direction of sand waves on the north slopes suggest a net accretion towards the southeast. On a daily scale, sedimenttransport is very variable in response to the strong tidal currents (Brockmann et al., 1981) and the breaking waves. A rather large sand accumulation, up to $6 \mathrm{~m}$ thick, was found southeast of Horns Rev about $13 \mathrm{~km}$ west of Fanø (Fig. 6). Flat, shingled reflectors suggest accretion towards the shore. The extent of this bank is not known.

\section{Discussion}

The geological history is divided into Saalian glacial processes forming a relative deep depression in the area followed by a series of depositional events in the latest Saalian, Eemian, Weichselian and Holocene, filling this local depocenter.

\section{Saalian}

The lower glacially deformed unit (LDGU, Table 1) comprises sediments of Miocene to Quaternary age resting on undeformed tertiary layers; thus it is interpreted as being of glaciotectonic origin (Huuse \& Lykke-Andersen, 2000; Andersen, 2004). The seismic records of Fanø Bugt show, that the LDGU was formed by glacial pressure from an easterly direction and indicate an eastward extension (beyond the seismic coverage, see Fig. 1) of the thrust complex. The Late Elsterian and the Late Saalian ice both advanced westwards across the area (Skibsted, 1992; Houmark-Nielsen, 2003). As no sequences older than the upper meltwater sand (SM, Tab.1) are available from borings, the exact age of the Fanø Bugt thrust complex is not known. Thus kineto-stratigraphy (Berthelsen, 1979) offers the best tool to relate the unit to the onshore glacial stratigraphy.

In the Esbjerg area, only $10 \mathrm{~km}$ east of the study-area at Fanø Bugt, similar large-scale glacial deformation is found. These also indicate ice movement from an easterly direction (Fig. 6) (Skibsted, 1992). The deformation involves Miocene and younger sediments including the Esbjerg Yoldia Clay, which is dated to the latest Elsterian-early Holsteinian by Knudsen and Penney (1987) and is discordantly overlain by a till with a typical 'Baltic' composition (Jessen, 1922). Thus, it may be concluded that the deformation in the Esbjerg area is Saalian. It should be mentioned though, that amino acid measurements, performed on mollusc shells by Miller and Mangerud (1996), suggest that the Esbjerg Yoldia Clay may be older than the Elsterian. If this is the case, the datings of the deformation and the offshore glacial deposits are more uncertain.

It is likely that the Fanø Bugt thrust complex continues onshore. By extrapolating the offshore décollement surface to Esbjerg it would be situated about $75-120 \mathrm{~m}$ higher than in adjacent parts of the Fanø Bugt study area. Hence, the slope of the décollement may cause the difference of about $70 \mathrm{~m}$, which is observed between the general level of the deformed units onshore and offshore. If this kineto-stratigraphic correlation is correct, the deformation in the Fanø Bugt is most likely related to the Late Saalian Baltic Advance which corresponds to the Warthe Stadial in northern Germany (Sjørring, 1983; Houmark-Nielsen, 2003). This correlation is discussed in detail elsewhere (Andersen, 2004).

The upper boundary of the LGDU is a glacial erosionunconformity (Fig. 5). The "ice sheet must thus have overridden the thrust complex after its formation. Maybe it eroded the valley and the higher parts of the marginal moraine in the 'Røde Klit Bank' area off the island of Rømø, leaving a more hilly terrain in the central part of the study area (Fig. 6). The meltwater sediments (SM I) were probably deposited during a small retreat. These were later overridden by a re-advance of the Warthe ice sheet, which subsequently deposited the upper till unit (SG III) at least $60 \mathrm{~km}$ west of the present day coast at Esbjerg (Fig. 3). The western extent of this ice advance is not located within the studied area. Based on the distribution of stony seabed, Pratje (1951) suggested that the Warthe stage ice border was situated about $7^{\circ} \mathrm{E}$; that is $100 \mathrm{~km}$ from the coast. This agrees with the distribution of supposed Saalian tills to the $55^{\circ} 45^{\prime} \mathrm{N}$ parallel (Foged, 1987), however the stratigraphic correlation with the Saalian stadials is uncertain. The deposition of the upper meltwater layer (SM) is the first event in the subsequent filling history of the large depocenter in the study area.

\section{Eemian}

The depositional conditions in the Eemian are discussed by Konradi et al. (2005). The conditions during the inundation and subsequent marine sedimentation seem to be very similar in the Eemian and Holocene. However, the Eemian sediments along the coast of Jutland appear to be deposited in sheltered fjords, estuaries, straits or tidal flats in an archipelago, probably protected by a row "of islands from the open North Sea. The highest parts of the Saalian glacial landscape formed the core of the islands.

\section{Weichselian}

During the Weichselian ice age (117 - $11.5 \mathrm{ka} \mathrm{BP}$ cal), the sea level dropped to more than $100 \mathrm{~m}$ below present day level (Streif, 2004), and the study area became land occupied by rivers or lakes. The Weichselian ice-cover did not reach the study area. However, it is generally assumed that the large alluvial outwash plains west of the ice margin in central Jutland extended into the North Sea area through valleys in the old Saalian landscape (Houmark-Nielsen, 2003). These outwash plains 'debouched' near present day sea level at Skjern, Varde and Kongeåen (arrows in Fig. 8) during the main 
Weichselian Advance (23 to $19 \mathrm{ka} \mathrm{BP}$ cal). Only the southern Kongeå- and Tinglev outlets south of Fanø carried meltwater during the late Weichselian Young Baltic Glaciation (19 - $17 \mathrm{ka}$ $\mathrm{BP}_{\text {cal }}$; Houmark- Nielsen \& Kjær, 2003). It is assumed that the meltwater-rivers continued westward and merged with the 'Elbe-Urstrom Tal' in the Heligoland Channel, in the central North Sea (Konradi, 2000; Houmark-Nielsen \& Kjær, 2003). With extrapolation of the onshore surface gradient of the distal parts of the alluvial plains from the Skjern- and Varde river valleys (about $70 \mathrm{~cm} \mathrm{~km}^{-1}$ ), the surface of these alluvial plains can be expected at ca. $-10 \mathrm{~m}$ DNN near the recent shoreline and at ca. $-25 \mathrm{~m} \mathrm{DNN} 20 \mathrm{~km}$ west of Blåvands Huk (Larsen, 2003). Here the meltwater streams would meet higher grounds on Vovov Bakke- $\varnothing$ and forced to flow either north or south, however, the outlet to the sea has not yet been located. It could suggest that the alluvial fan north of Horns Rev was active during the main Weichselian, while the down-cutting and infilling of the Horns Rev valley was related to the Young Baltic Glaciation (19 - 17 ka BP cal; Houmark- Nielsen \& Kjær, 2003). However, the link between the onshore outwash plains, the Horns Rev Valley and the outlet of the valley are unknown.

\section{Holocene}

Based mainly on geomorphology it has earlier been suggested that the Horns Rev was a system of Saalian terminal moraines pushed up by ice from a northern direction (Jessen, 1925; Reinhard, 1974; Lüneburg, 1967). The gravel content on the reef, but absence of stones, was explained by assuming that the moraines mainly consisted of glacial floes of meltwater deposits. The evidence illustrated in Figs. 10 and 11 is not in support of this suggestion. The Horns Rev clearly is a Holocene feature.

Due to a quick rise in relative sea level between $8800 \mathrm{BP}_{\text {cal }}$ and ca. $7000 \mathrm{BP}_{\text {cal, }}$, the accommodation space was quickly reestablished. In spite of a very exposed setting, the Blåvands Huk - Horns Rev area became a major Holocene depocenter for sediments transported southward along the west coast, as well as for material transported along the seafloor. The deposition in the coastal area and on the marine foreland down to Blåvands Huk seems to be a wave-dominated, forced regressive spit complex (Jessen, 1925; Nielsen \& Johannessen, 2001) much strengthened by aeolian deposition (Clemmensen, 1999). Here the amplitude of the tide increases and strong and complex current patterns are generated in interaction with the Horns Rev topography, thus the mean tidal range is reduced from $1.5 \mathrm{~m}$ south of Horns Rev to $0.5 \mathrm{~m}$ north of the reef (Brockmann et al., 1981). According to Nielsen and Johannessen (2001) a spit system may develop where wave-induced currents favour shore parallel sediment transport in a microtidal setting, while strong tidal currents favour sediment transport perpendicular to the coast. The interaction between the two sedimentary environments may thus contribute to an explanation of the 'inverse T shaped' sand accumulation in the Blåvands Huk area and the change in direction of the sediment flow.

The morphology of the Inner Horns Rev resembles the submarine morphology around the outlets of the tidal channels in the Wadden Sea (cf. Danish Nautical Map 94). Based on old maps and observations of remnants of beach ridges obliquely cut by the coast, both Schipull (1990) and Bartholdy and Pejrup (1994) argued, that the inner part of the Inner Horns Rev actually was land a few hundred years ago. Thus it could be argued that this area together with Blåvands Huk, north of Skallingen, is a remnant of a partly submerged tombolo.

How the Outer Horns Rev was formed is not clear. The size, the morphology and the orientation in relation to the tidal currents (Brockmann et al., 1981) of the Outer Horns Rev resembles the tidal current ridges described from the southern North Sea (Houbolt, 1968). Prograding reflectors and direction of sand waves on the north slopes suggest a net accretion towards southeast. This is in agreement with the annual average direction and magnitude of recent sediment transport as modelled by the Danish Hydraulic Institute (Pers. comm., 2001).

\section{Conclusions}

The stratigraphically oldest unit (LDGU, Table 1) was only studied in the Fanø Bugt area. This unit consists of Neogene and Quaternary sediments deformed by large-scale glaciotectonics to a depth of $200-360 \mathrm{~m}$ below sea level. A kinetostratigraphic correlation to onshore suggests that the deformation took place during a westward advance stage of the Late Saalian (Warthe) glaciation. The top of the deformed units (reflector C, Table 1 and Fig. 3) is a glacial erosional unconformity. It is suggested that the same ice advance, which caused the glaciotectonics, subsequently eroded the top of the thrust sheets, deposited a layer of meltwater sediments and at a later stage an upper glacigene unit, which was observed c. $30 \mathrm{~km}$ offshore. Thus the limits of the Warthe advance in the area may have been situated further to the west than previously thought. However, the exact position of the maximum extent of the ice margin is unknown.

The surface of the glacial Saalian landscape forms a wide depression to about $50 \mathrm{~m}$ below sea level, providing the accommodation space that controlled the deposition since late Saalian time. Deposition of meltwater sediments, presumably from the latest Saalian (SM, Table 1), was the first episode of infilling of this basin. Subsequently $10 \mathrm{~m}$ of marine shallowwater silts (Eem, Table 1) were deposited in a sheltered archipelago during Eemian time. During the Weichselian it is likely that the distal parts of meltwater alluvial fans (WS, Table 1) covered the basin floor, although most of these sediments have now been eroded. A $5 \mathrm{~km}$ wide and $50 \mathrm{~km}$ long Weichselian valley was eroded into or through the Eemian deposits and 
subsequent filled with meltwater deposits (WS in valley, Table 1). It is suggested that the alluvial fan north of Horns Rev was active during the main Weichselian Advance (24 to $19 \mathrm{ka} \mathrm{BP}$ ), while erosion and infilling of the Horns Rev valley was related to the Young Baltic Glaciation (19 - $17 \mathrm{ka} \mathrm{BP}$ ).

An erosional surface, 20 - 30 m below present day sea level, forms the base of the Holocene marine deposits and extends several kilometres eastwards, below the onshore coastal areas and below the northern Wadden Sea (Fig. 8). The Holocene rise of sea level led to re-establishment of the sedimentary basin including extensive areas that are now land. The Weichselian outwash plains are presumably eroded in the coastal areas and do not play a role in the present day position of the coast. This is in agreement with the conclusions regarding the formation of the spit closing the Ringkøbing Fjord (Anthony \& Møller, 2002). Coastal sediment transport from the north has fed the development of a huge spit complex in the basin forming the Blåvands Huk/Skallingen and Ho Bay area. The aggradation of the west coast is still in progress.

The development of the Inner Horns Rev, protruding into the North Sea west of the Huk, seems to be a young or recent extension of this system. Sediment transport within the seabed from the west and south provides another major sediment source. Thick sequences of Holocene marine sediments fill the western deeper part of the basin, partly as eastward prograding units. The east-west trending sandbanks of Outer Horns Rev have developed from spit complexes and were later modified by sand deposition to form a tidal current ridge. The strongly wave-exposed part of the Eastern North Sea off the westernmost point of Denmark, where the simplified west coast of Jutland meets the mesotidal Wadden Sea, must be regarded as a major depocenter comparable to the Skagen Odde situated in the northernmost part of Denmark between the Skagerrak and Kattegat straits (Nielsen \& Johannessen, 2001).

\section{Acknowledgements}

The project was financed by the Geological Survey of Denmark and the Danish Research Agency. The Danish Coastal Protection Board, A/S Elsam and DONG placed valuable data at our disposal. P. Roll Jakobsen, A. Kuijpers, J. Leth, H. Lykke-Andersen and M. Houmark-Nielsen and to reviewers are thanked for valuable discussions. B.M. Schack, E. Melskens changed our sketches into drawings. D. Ryves kindly improved the language. A special thanks to all the colleagues who took part in the fieldwork on all kinds of vessels through the years. This manuscript is published with permission of the Geological Survey of Denmark and Greenland.

\section{References}

Aagaard, T., Nielsen, N. \& Nielsen, J., 1995. Skallingen-origin and evolution of a barrier spit. Meddelelser fra Skalling-Laboratoriet XXXV, København 1995: 1-85.

Andersen, L.T., 2004. The Fanø Bugt Glaciotectonic Thrust Fault Complex, Southeastern Danish North Sea. Ph.D.Thesis 2004. Danmarks og Grønlands Geologiske Undersøgelse Rapport 2004/30: 35-68.

Anthony, D. \& Møller, I., 2002. The geological architecture and development of the Holmsland Barrier and Ringkøbing Fjord area, Danish North Sea coast. Danish Journal of Geography 102: 27-36.

Bartholdy, J. \& Pejrup, M., 1994. Holocene evolution of the Danish Wadden Sea. Senckenbergiana maritima 24: 187-209.

Berthelsen, A., 1979. The methodology of kineto-stratigraphy as applied to glacial geology. Bulletin of the Geological Society of Denmark 27 Special Issue: $25-38$.

Brockmann, C., Lange, W., Mittelstaedt, E. \& Soetje, K.C., 1981. The tidal stream in the German Bight. Deutsche Hydrographische Zeitschrift 34 (2): $56-60+$ Plate 1.

Clemmensen, L.B., 1999. Holocene evolution of the Vejers-Skallingen barriere spit, Denmark. Excursion B2. In: Pedersen, G. K. \& Clemmensen, L.B. (eds): IAS. Copenhagen 1999, Field Trip Guidebook. 19th Regional European Meeting of Sedimentology Aug. 24-26.Copenhagen: 93-102.

Clemmensen, L.B. Andreasen, F., Nielsen, S.T. \& Sten, E., 1996. The late Holocene coastal dunefield at Vejers, Denmark: characteristics, sand budget and depositional dynamics. Geomorphology 17: 79-98.

Davis, R.A., Bartholdy, J., Pejrup, M. \& Nielsen, N., 1997. Stratigraphy of Skallingen - A Holocene barrier in the Danish Wadden Sea. Aarhus Geoscience 7: 9-19.

DGI, 1982. Horns Rev, Ressourceundersøgelser fase 1-4, Geoteknisk Rapport 2, 2 bind. Ref. 4742-75. Rapport til Fredningsstyrelsen 9. kontorHavbundsundersøgelser.

Ehlers, J., 1990. Reconstructing the dynamics of the north-west European Pleistocene ice sheets. Quaternary Science Reviews 3: 1-40.

Foged, $N$., 1987. The need of Quaternary geological knowledge in geotechnical engineering. Boreas 16: 419-424.

Gripp, K., 1944. Entstehung und künftige Entwicklung der Deutschen Bucht. Auf dem Archiev der Deutschen Seewarte und das Marineobservatoriums 63 (2): 1-42.

Houbolt, J.J.H.C., 1968. Recent sediments in the southern bight of the North Sea. Geologie en Mijnbouw 47: 245-237.

Houmark-Nielsen, M., 2003. The Pleistocene of Denmark: a review of stratigraphy and glaciation history. In: Ehlers, J. \& Gibbard, P. (eds): Quaternary Glaciation-extend and chronology. Vol. 1 Europe. Elsevier (Amsterdam): 321-336.

Houmark-Nielsen, M. \& Kjær, K.H., 2003. Southwest Scandinavia, 40-15 kyr BP: paleogeography and environmental change. Journal of Quaternary Science 18: 769-786.

Huuse, M. \& Lykke-Andersen, H., 2000. Large-scale glaciotectonic thrust structures in the eastern Danish North Sea. In: Maltman, A., Hambrey, M. \& Hubbard, B. (eds): Deformation of Glacial Materials. Geological Society, London, Special Publications 176: 293-305. 
Jarke, J., 1956. Der Boden der südlichen Nordsee. I Eine neue Bodenkarte der südlichen Nordsee. Deutschen Hydrographischen Zeitschrift 9:1-9 and map.

Jessen, A., 1922. Geologisk kort over Danmark, Kortbladet Varde. Danmarks geologiske Undersøgelse 1. række Nr. 14: 1-95.

Jessen, A., 1925. Geologisk kort over Danmark, Kortbladet Blåvandshuk. Danmarks geologiske Undersøgelse 1. række Nr. 16: 1-68.

Knudsen, K.L. \& Penney, D.N., 1987. Foraminifera and 0stracoda in Late Elsterian-Holsteinian deposits at Tornskov and adjacent areas in Jutland, Denmark. Danmarks geologiske Undersøgelse Ser. B Nr. 10: 1-67.

Konradi, P., 2000. Biostratigraphy and environment of the Holocene marine transgression in the Heligoland Channel, North Sea. Bulletin of the Geological Society of Denmark 47: 71-79.

Konradi, P., Larsen, B. \& Sørensen, Aa.B., 2005. Marine Eemian in the Danish eastern North Sea. Quaternary International 133-134: 21-31.

Krog, H., 1979. Late Pleistocene and Holocene shorelines in Western Denmark. In: Oele, E., Schüttenhelm, R.T.E. \& Wiggers J.D. (eds): The Quaternary History of the North Sea. Acta Universitatis Upsaliensis Annum Quengentesimum Celebrantis 2. (Uppsala): 75-83.

Kuijpers, A., 1993. Supplerende Seismiske undersøgelser i område 524 Horns Rev. DGU Kunde rapport nr. 76. 1993: 1-18.

Kuijpers, A., 1995. The Late Quaternary sediment distribution in the DK sector of the North Sea: Area 582 and 524. DGU Datadocumentation no 13. 1995: 1-13.

Kystdirektoratet, 2001. Kystdirektoratets program for Undersøgelser and Udvikling, 1998 - 2001, Slutrapport. Kystdirektoratets kysttekniske afdeling 2, edition Dec. 2001. Lemvig. 36 pp.

Kystinspektoratet, 1998. Menneske, Hav, Kyst og Sand. Thyme, F. (ed.) Kystinspektoratet 1973-1998. Lemvig. 95 pp.

Larsen, B. \& Leth, J.O., 2001a: Geologisk kortlægning af Vestkysten. En vurdering af aflejringsforholdene $i$ området mellem Nymindegab og Horns Rev. GEUS Rapport 2001/92, Vol. 1 Text, 1-44 and vol. 2 Data. Geological Survey of Denmark and Greenland.

Larsen, B. \& Leth, J.O., 2001b. Geologisk kortlægning af Vestkysten. Regionalgeologisk tolkning og en samlet vurdering af aflejringsforholdene i området mellem Nymindegab og Horns Rev. GEUS Rapport 2001/96, Vol. 1 Text: 1-83 and vol. 2. Data. Geological Survey of Denmark and Greenland.

Larsen, B., 2003. Blåvands Huk-Horns Rev området - et nyt Skagen? Geologi. Nyt fra GEUS Nr. 4 December 2003: 1-11.

Lauersen, G.V., 1995. Foraminiferal biostratigraphy of Cenozoic sections in five wells from the Danish area. EFP project-92: Basin development of the Tertiary of the Central Trough with emphasis on possible hydrocarbon reservoirs. Report nr. 20 University of Aarhus / Geological survey of Denmark.

Leth, J.O., 1996. Late Quaternary geological development of the Jutland Bank and the initiation of the Jutland Current, NE North Sea. NGU. Bulletin, 430: 25-34.

Leth, J.O., Larsen, B. \& Anthony, D., 2004. Sediment distribution and transport in shallow coastal waters along the Danish west coast. Geological Survey of Denmark and Greenland Bulletin 4: 41-44.

Lüneburg, $\boldsymbol{H}$., 1967. Eigenschaften und Verteilung der Sedimente am Hornsriff. Veröffentlichungen des Institut für Meeresforschung in Bremerhaven 10: 187-208.

Miller, G.H. \& Mangerud, J., 1996. Aminostratigraphy of European Marine Interglacial Deposits. Quaternary Science Reviews 4: 215-278.
Mitchum, R.M., Vail, P.R. \& Sangree, J.B., 1977. Seismic stratigraphy and global changes of sea level, Part 6. Stratigraphic interpretation of seismic reflection patterns in depositional sequences. In: Payton, C.E. (ed.): Seismic Stratigraphy-application to hydrocarbon exploration. American Association of Petroleum Geologists Memoir 26: 117-133.

Nielsen, L.H. \& Johannessen, P.N., 2001. Accretionary, forced regressive shoreface sands of the Holocene-Recent Skagen Odde spit complex, Denmark - a possible outcrop analogue to fault-attached shoreface sandstone reservoirs. In: Martinsen, 0.J. \& Dreyer, T. (eds): Sedimentary Environments Offshore Norway-Palaeozoic to Recent. NPF Special Publication 10. Elsevier Science B.V. Amsterdam: 457-472.

Nielsen, S.T., Clemmensen, L.B. \& Andreasen, F., 1995. The middle and late Holocene barrier spit system at Vejers, Denmark: structure and development. Bulletin of the Geological Society of Denmark 42: 105-119.

Noe-Nygaard, A., 1992. Larvikiter i kvaderstenskirker, Et argument for en 'gammel norsk isstrøm' i tidlig Weichsel. DGU. Miljøministeriet. Copenhagen: $1-32$.

Petersen, K.S., 1998. Den holocene marine udvikling ved Limfjordstangerne og tilgrænsende dele af Nordsøen-Jyske Rev, belyst ved molluskfaunaen. Limfjordsprojektet, rapport nr. 8, 1998: 303-323.

Pratje, O., 1951. Die Deutung der Steingründe in der Nordsee als Endmoränen. Deutsche Hydrograpische Zeitschrift 4 (3): 106-114 + Tafel 7.

Rasmussen, E.S., 2003. Sedimentologiske og stratigrafiske undersøgelser af de miocæne aflejringssystemer i Jylland. Geologisk Tidskrift (2): 3-4.

Reinhard, H., 1974. Genese des Nordseeraumes im Quartär. Societas Geographica Fenniae, Helsingfors, Fennia 129: 1-95.

Schipull, K., 1990. Blåvandshuk und Skagen Odde-zur Grundrissentwicklung zweier markanter Küstenvorsprünge der Halbinsel Jütland, Dänemark. Mitteilungen Geographische Gesellschaft in Hamburg 80: 557-571.

Sjørring, S., 1983. The glacial history of Denmark. In: Ehlers, J., (ed.): Glacial deposits in north-west Europe. A. A. Balkema (Rotterdam): 163-179.

Skibsted, S., 1992. På sporet af gammel kulde og varme. Varv : 73-89.

Stewart, F.S. \& Stoker, M.S., 1990. Problems associated with seismic facies analysis of diamicton-dominated, shelf glacigenic sequences. Geo-Marine Letters 10: 151-156.

Streif, H., 2004. Sedimentary record of Pleistocene and Holocene marine inudations along the North Sea coast of Lower Saxony, Germany. Quaternary International 112: 3-28.

Stuiver, M., Reimer, P.J., Bard, E., Beck, J.W., Burr, G.S., Hugghen, K.A., Kromer, B., Maccormac, G., Van der Plicht, J. \& Spurk, M., 1998. INTCAL98 Radiocarbon Age Calibration, 24.000-0 cal BP. Radiocarbon 40: 1041-1083. 